\section{Vietnam Journal of Agricultural Sciences}

\title{
Vietnamese Tea Exporting and Forecasting to 2030
}

\author{
To The Nguyen ${ }^{1,2}$, Nguyen Anh Tuan² \& Le Phuong Thao ${ }^{1}$ \\ ${ }^{1}$ Faculty of Economics and Rural Development, Vietnam National University of Agriculture, \\ Hanoi 131000, Vietnam \\ ${ }^{2}$ Faculty of Political Economics, Vietnam National University, Hanoi 122000, Vietnam
}

\begin{abstract}
This study aimed to determine the factors influencing Vietnamese tea export quantities, namely, the internal factors of national tea production, productivity, and cultivated areas, and the external factors of export price and world tea export quantity (excluding Vietnam). We employed a time-series linear model to estimate the magnitude as well as the sign of the aforementioned factors on Vietnam's tea export quantity and two Box-Cox transformations called a simple back-transformed forecast and a bias-adjustment to forecast the growth rate of the Vietnamese tea export quantity until 2030. The results suggested that except for the total domestic tea production, all the proposed factors significantly affected the Vietnamese tea export quantity. The tea export quantity of other nations around the world had a significantly negative impact on Vietnamese tea that led to Vietnam's tea exports dropping by 34 tons on average since the other countries exported 1,000 tons of tea. The forecasted outcome suggested an upward trend of Vietnamese tea exports up to 2030. In order to sustainably develop Vietnam's tea industry, we recommend that the government should take supportive actions such as investing in in-depth tea processing to improve Vietnam's tea export quality, focusing on post-harvest activities, investing in organic or high-value tea rather than conventional tea, continuing to accumulate land to support the growth of cultivated tea areas, and maintaining high productivity by using hybrid seeds.
\end{abstract}

\section{Keywords}

Tea export, Vietnam, forecast

Received: July 3, 2020

\section{Introduction}

Coffee, tea, and pepper are the three main industrial crops of Vietnam that have significantly contributed to Vietnam's GDP after Doi Moi (Tuan, 2019). Recently, tea has become an important crop because it offers certain advantages, in particular, it may help to fight against erosion and runoff in the mountains. It also helps to further 
combat poverty in rural regions because it can bring daily income for farmers. According to Vitas (2012), Vietnam had approximately 400 thousand tea producers almost a decade ago, mostly concentrated in major producing regions such as the North Mountain (about 60\%) and the Central Highlands (about 20\%). Furthermore, the tea sector in Vietnam is occupied by six million rural workers. However, the size of average tea production remains relatively small, about $70 \%$ of households grow tea on an area of less than 0.2 hectares.

Notably, tea production is generally present in the six regions of Vietnam, namely the Northwest, Northeast, North Mountain, North Central, Central Highlands, and Central Coast. Tea production is concentrated in such provinces as Phu Tho, Thai Nguyen, Yen Bai, Lam Dong, and Gia Lai, among others. The North Mountain region includes some provinces such as Phu Tho, Thai Nguyen, and Yen Bai. This region accounts for about $60 \%$ of the total area of tea plantations in Vietnam. Meanwhile, the Central Highlands region includes Lam Dong and Gia Lai. This region represents more than $20 \%$ of the total tea area in Vietnam (Table 1).

In detail, the production of tea in Vietnam has increased significantly since the 90s, mainly due to the expansion of tea production areas and the growth of tea productivity. In the year 1990, tea in Vietnam was grown on about 44 thousand hectares. However, this area increased by 2.5 times in 2012. During the period from 1990 to 2010 , the amount of land used for growing tea increased by $4.46 \%$. Similarly, during the period from 1990 to 2010, Vietnam witnessed an increase in tea production in general. The quantity of tea production consequently increased by about 9.05 tons at the same time. In 1990, the total tea production was about 32 thousand tons; meanwhile, it reached about 216 thousand tons in 2012 (Vitas, 2012). Notably, this production was distributed between small farmers $(70 \%)$ and large public agricultural institutions (30\%). In a GSO report (2019), the total tea production of Vietnam continued to grow annually up to 994.2 thousand tons in 2018 with a cultivation area of 108.3 thousand ha.

Petrakis et al. (2015) argued that the global economic development had slowed down since the Great Recession in 2008, followed by the unstable economic development that affected fluctuations in the quantities of tea exports. GSO (2019) reported that Vietnam's exported tea quantity witnessed a downfall in the period of 2013-2016; meanwhile, the aforementioned tea production and cultivation areas kept growing. In addition, the global tea sector witnessed an increase in tea export quantity in this period (FAO, 2018). The situation raised three research objectives. Initially, an overview of Vietnam tea was required as a systematical report to fully capture the overall picture of Vietnam's tea industry development after Doi Moi. Secondly, what were the determinants of tea export quantity, namely the total tea production, tea production areas, tea productivity, and tea price, that empirically affected the reduction of Vietnam's tea export quantity? Thirdly, predictions about tea export quantities in the

Table 1. Distribution of tea area in Vietnam (\%)

\begin{tabular}{cccccccccc}
\hline \multirow{2}{*}{ Region } & \multicolumn{1}{c}{ Year } \\
\cline { 2 - 10 } & 2002 & 2003 & 2004 & 2005 & 2006 & 2007 & 2008 & 2018 \\
\hline North Mountain & 57.98 & 58.21 & 58.14 & 57.13 & 56.99 & 56.87 & 57.05 & 81.94 \\
Central Highlands & 23.78 & 22.62 & 22.07 & 21.41 & 20.83 & 20.84 & 21.07 & 12.56 \\
Northwest & 7.27 & 7.47 & 7.68 & 9.25 & 9.75 & 9.72 & 9.54 & 13.58 \\
North Central & 7.25 & 7.93 & 7.29 & 8.06 & 8.08 & 8.17 & 8.02 & 11.22 \\
Northeast & 2.32 & 2.50 & 2.57 & 1.98 & 2.24 & 2.32 & 2.27 & 5.06 \\
Central Coast & 1.40 & 1.27 & 2.25 & 2.17 & 2.11 & 2.08 & 2.05 & 6.01 \\
\hline
\end{tabular}

Source: GSO (2019) and our calculations 
coming years should be estimated to provide an outlook for policymakers as well as tea farmers to help them decide whether to focus on tea exports or the domestic market.

Our analysis used a regression model to gather all the potential determinants influencing Vietnam's tea export quantity as the regression input, namely tea production, tea production areas, tea productivity, and tea price (Kingu, 2016), and world tea output (Miano, 2010). Accordingly, a forecasting function was employed to estimate the quantity of tea exports with Box-Cox transformations to correct the bias caused when using time-series data. This gave median forecasts on the original scale.

\section{Methodology}

\section{Data collection}

Our study employed secondary data to gather a sufficient amount of required information to input into our models as well as our predicted tea export quantity for the next 10 years. The secondary data were sourced from the annual reports of FAO about Vietnam's tea export quantity, total domestic production quantity, and total production areas, total world production, and lastly, the export price for Vietnamese tea. We also sought and gathered data from the Vietnam General Statistics Office related to tea cultivation land area in the whole territory up to 2018. The data range was from 1961 up to 2018 because having time-series data containing 58 years might increase the reliability of our results. The data we collected were based on our research concerns in the previous section that principally contained information of the tea production situation of Vietnam for 58 years such as the total planted area, total output, total productivity, tea price, and total world teaproducing quantity.

\section{Data analysis}

The descriptive statistical method was used for the analyses to synthesize the mean values of the employed variables which are illustrated in Table 5 representing the characteristics of the total tea production, tea production area, tea productivity, and tea export price.

The time-series linear regression was used to estimate the impact of tea export quantity determinants such as the total domestic production, tea production areas, tea productivity, and tea export price, and was indicated as a general form provided in the studies of Serletis (1992), Uk Polo (1994), and Amirkhalkhali \& Dar (1995):

Export $_{t}=\alpha_{1 t}+\beta_{1 t}$ Prod $_{t}+\beta_{2 t}$ Area $_{t}+$ $\beta_{3 t}$ Productivity $_{t}+\beta_{4 t}$ Price $_{t}+\beta_{5 t}$ Wprod $_{t} \varepsilon_{t}$ (1)

where Export $t_{t}$ is the dependent variable which was the quantity of Vietnam's tea exports, the independent variables included $\operatorname{Prod}_{t}$, Area ${ }_{t}$, Productivity $_{t}$, Price $_{t}$, and Wprod ${ }_{t}$, and finally $\varepsilon_{t}$ is the error term. Prod $_{t}$ stands for total tea domestic production at time $t$. Similarly, Areat, Productivity $_{t}$, and Price $t$ are the total planted areas, productivity, and price of Vietnamese tea at time $t$, respectively. Lastly, $\operatorname{Wprod}_{t}$ is the world total tea production with Vietnam excluded.

To our forecast function, we used the BoxCox transformation (back-transform). If the data show variation that increases or decreases with the level of the series, then a transformation can be useful. For example, a logarithmic transformation is often useful. If we denote the original observations as Export ${ }_{1, . ., \text { Export }_{58} \text { and }}$ the transformed observations as $w_{1}, . ., w_{58}$ we can calculate the following formula: $w_{1, \ldots, 58}=$ $\log \left(\right.$ Export $\left._{1, . .58}\right)$. One useful feature of $\log$ transformations is that they constrain the forecasts to stay positive on the original scale. A useful family of transformations that includes both logarithms and power transformations is the family of Box-Cox transformations, which depend on the parameter $\lambda$ and are defined as follows:

Export $t_{t}=\left\{\begin{array}{c}\exp \left(w_{t}\right) \text { if } \lambda=0 \\ \left(\lambda w_{t}+1\right)^{1 / \lambda} \text { if otherwise }\end{array}\right.$

where $t$ runs from 1 to 58. However, one issue with using mathematical transformations such as Box-Cox transformations is that the 
back-transformed point forecast will not be the mean of the forecast distribution. In fact, it will usually be the median of the forecast distribution (assuming that the distribution on the transformed space is symmetric). For many purposes, this is acceptable, but occasionally the mean forecast is required. For example, you may wish to add up sales forecasts from various regions to form a forecast for the whole country. But medians do not add up, whereas means do. The difference between the simple backtransformed forecast and the mean given by biasadjustment is called the bias. When we use the mean, rather than the median, our analysis estimates for the point forecasts have been biasadjusted.

\section{Results and Discussion}

\section{Overview of tea production and exports in Vietnam}

During the period from 2005 to 2012, tea productivity increased by about $4.73 \%$ per year. However, as can be seen in Table 2, the tea export quantity of Vietnam tremendously decreased from 2013 to 2016 (3.12\%), and then quickly boosted from 2017 to 2018 (4.56\%), which signifies a good sign that the tea industry of Vietnam was able to quickly adapt to changes.

Furthermore, the productivity of tea depends on the tea varieties, farming techniques, and surface and environmental conditions specific to the geographical position of the plantations. There are many varieties of tea in Vietnam such as Bat Tien, LDP1, TRI 777, Trung-Du, PH1, and PH3, among others. However, some old varieties of tea such as Trung-Du and PH1 still make up the majority, and hence, the strategy of Vietnam is to gradually replace these old varieties. In general, old varieties of tea bring low productivity, for instance, the productivity of the traditional tea variety Trung-Du is about 4 tons per hectare, and the productivity of the other old tea variety, $\mathrm{PH} 1$, has about 6.5 tons per hectare (Cuong, 2006). Meanwhile, in other regions, tea producers began growing new varieties of tea that have higher productivity, such as in Son La where the average productivity reached 12 tons per hectare (Tran et al., 2004). According to Saigenji \& Zeller (2009), there is also a big difference between the productivity of small farmers and big farmers, or non-contract and contract farmers (3.3 and 9.6 tons per hectare, respectively).

In addition, approximately $70 \%$ of the tea produced in Vietnam was exported. In particular, tea is exported through three main ways: (i) state enterprises; (ii) joint ventures and foreign companies; and (iii) private companies. Notably, about $98 \%$ of tea exports are in the form of raw materials. This explains why tea exporters do not have a high added value. Regarding the exported tea, Vietnamese tea is exported to more than one hundred countries around the world, although the tea exports are focused mainly on such countries as Pakistan, Russia, Taiwan, Iraq, China, and India.

According to Table 3, Taiwan and Pakistan were the two largest importers of Vietnamese tea, which accounted for roughly $35 \%$ of the total quantity of tea exported in the period of 2000 to 2018. Russia was the third-largest importer of Vietnamese tea with an export value reaching 12.88 million dollars and holding about $10 \%$ of the market share of Vietnam's tea exports. Moreover, the growth rate of the export value increased by $21 \%$ per year. Iraq was also one of the largest importers of Vietnamese tea and held around $8 \%$ of the market share of Vietnam's tea exports. The average tea export value reached

Table 2. The growth of tea production in Vietnam (1990-2018) (\%)

\begin{tabular}{ccccccc}
\hline Periods & $1990-1997$ & $1998-2004$ & $2005-2012$ & $2013-2016$ & $2017-2018$ & Average \\
\hline Surface Area & 6.26 & 5.54 & 2.45 & 2.34 & 4.01 & 4.46 \\
Productivity & 1.98 & 7.32 & 4.73 & 3.12 & 4.56 & 4.39 \\
Production & 8.36 & 13.26 & 7.29 & 5.12 & 6.14 & 9.05 \\
\hline
\end{tabular}

Source: FAOSTAT (2018) and our calculations. 
10.42 million dollars. Nevertheless, the growth rate of the export value decreased by $23 \%$ per year. Similarly, China was also a vital tea market for Vietnam. The average export value of tea reached around 6 million dollars. Although it held just $7.8 \%$ of the market share of Vietnamese tea exports, the growth rate of the export value increased significantly. It increased on average $42 \%$ per year in recent years. Besides, the growth rate of the tea export value in India decreased by $6 \%$ per year.

Table 4 shows that the growth rate of the tea export quantity increased an average of $10.57 \%$ during the period from 1990 to 2018. However, in recent years the growth rate of the tea export quantity tended to decrease. Although export quantities decreased by $12.68 \%$ in the period of 1990 to 1997 , it strongly increased during the period 1998 to 2004, reaching $21.08 \%$, and then decreased by $7.57 \%$ during the period from 2005 to 2012. However, from 2013-2016, Vietnam witnessed a significant drop in the tea export quantity leading to the decrease of the tea export value by $1.27 \%$.

On the contrary, the growth rate of the tea export value tended to increase, which explains why tea exports in Vietnam have made considerable progress by diminishing the volume

Table 3. The main export markets of Vietnamese tea in the period of 2000-2018

\begin{tabular}{cccc}
\hline Country & Market share (\%) & Exports value (million USD) & Growth (\%) \\
\hline Pakistan & 20.85 & 26.88 & 16.4 \\
Taiwan & 14.48 & 18.66 & 10.8 \\
Russia & 9.99 & 12.88 & 21.1 \\
Iraq & 8.08 & 10.42 & -23.3 \\
China & 6.10 & 7.86 & 42.4 \\
India & 3.59 & 4.62 & -6.0 \\
Indonesia & 3.07 & 3.96 & 27.3 \\
Germany & 2.90 & 3.73 & 12.6 \\
UAE & 2.52 & 3.25 & 34.4 \\
USA & 2.30 & 2.96 & 29.1 \\
Poland & 2.21 & 2.85 & 7.6 \\
Saudi Arabia & 2.18 & 2.81 & 25.1 \\
Japan & 1.22 & 1.57 & -9.9 \\
Philippines & 1.07 & 1.37 & 56.4 \\
Malaysia & 1.02 & 1.32 & 28.6 \\
\hline
\end{tabular}

Source: FAO (2018) and our calculations.

Table 4. Growth rate of tea export quantity and value in Vietnam (1990-2018)

\begin{tabular}{ccccccc}
\hline Periods & $1990-1997$ & $1998-2004$ & $2005-2012$ & $2013-2016$ & $2017-2018$ & Average \\
\hline Exports quantity (\%) & 12.68 & 21.08 & 7.57 & -5.58 & 15.78 & 10.57 \\
Exports value (\%) & 11.80 & 11.44 & 12.75 & -1.27 & 11.73 & 10.56 \\
Exports quantity (000 tons) & 19.21 & 61.73 & 120.25 & 80.42 & 158.34 & 97.32 \\
Exports value (mil. USD) & 24.12 & 68.64 & 161.56 & 109.43 & 265.95 & 105.51 \\
\hline
\end{tabular}

Source: FAO (2018) and our calculations. 
and improving the quality. To be more precise, as shown in Table 4, the export value increased around $11.8 \%$ in the period of 1990 to 1997 , by $11.4 \%$ in the period of 1998 to 2004, and by $12.75 \%$ in the period of 2005 to 2012 . Overall, the growth rate of the tea export value increased by $10.56 \%$ during the period from 1990 to 2018 . On the contrary, under the impact of global tea demand, the growth rate of the tea export quantity and value were reduced by $5.58 \%$ and $1.27 \%$, respectively, in the period of 2013-2016. Since 2017, the tea export quantity has significantly increased, followed by the tea export value. As can also be seen from a set of sub-figures in Figure 1, the phenomenon of decreased tea export quantity is illustrated while the production quantity, production areas, and productivity continued to grow.

Under different aspects, Table $\mathbf{4}$ also shows that the quantity of the exported tea had increased by an average of 97.32 thousand tons during the period from 1990 till 2018. Although it decreased by roughly 40 thousand tons in the period of 2013-2016, during the preceding period from 2005 to 2012 it increased by 120.2 thousand tons, and increased by 77.92 thousand tons during the period from 2017 to 2018 . Similarly, the value of the exported tea increased more significantly than the quantity of the exported tea. To be more precise, as shown in Table 4, the value grew by 24.1 million dollars in the period of 1990 to 1997, rose by 68.6 million dollars in the next

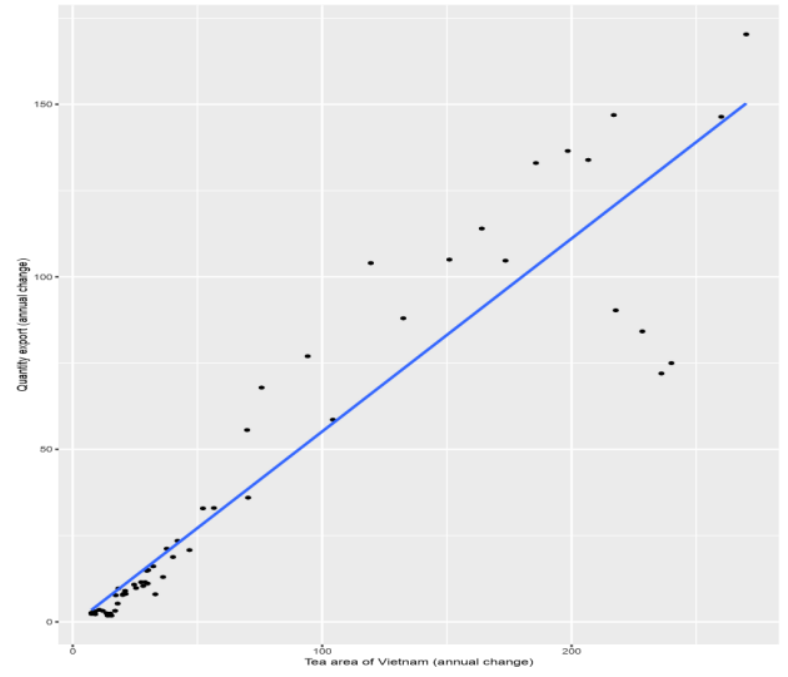

(a) Export quantity vs. productivity from 1961 to 2018 period from $1998-2004$, and by 161.5 million dollars in the period of 2005 to 2012. Overall, the value of the exported tea increased on average by 105.51 million dollars during the period from 1990 till 2018.

Figure 2 indicates the relationship between the regressor, namely the tea export quantity, and the explanatory variables. It can be seen that except for the export price, all the remaining regressands are more likely to explain the tea export quantity. This is not unexpected because the tea export price depended on the global market price while tea production was still based on the national production capacity.

\section{Determinants of Vietnamese tea export quantity}

The descriptive collected data are displayed in Table 5. We can easily observe the large standard deviations of each variable in the table that explicitly signify changes in the tea export quantity and total production quantity. On average, Vietnam has exported 40.91 tons of tea to the world market with a price of USD 1,230 per ton. The tea export price was less likely to change throughout the 58 years, which can be seen by the relatively small standard deviation at USD 0.27 per kg. As can be seen in Figure 3, the tea production quantity had a large expansion from 2000 up to 2018, followed by tea productivity that implicitly indicates the latent effectiveness of Vietnamese government policies in terms of stimulating the development of the tea

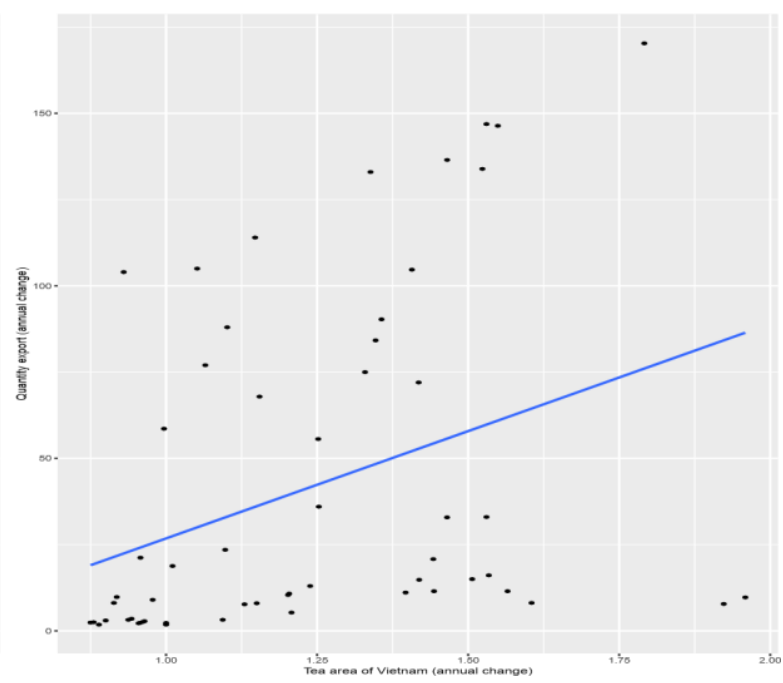

(b) Export quantity vs. export price from 1961 to 2018

Figure 1. Time trend of Vietnam's export quantity and other criteria from 1961 to 2018 


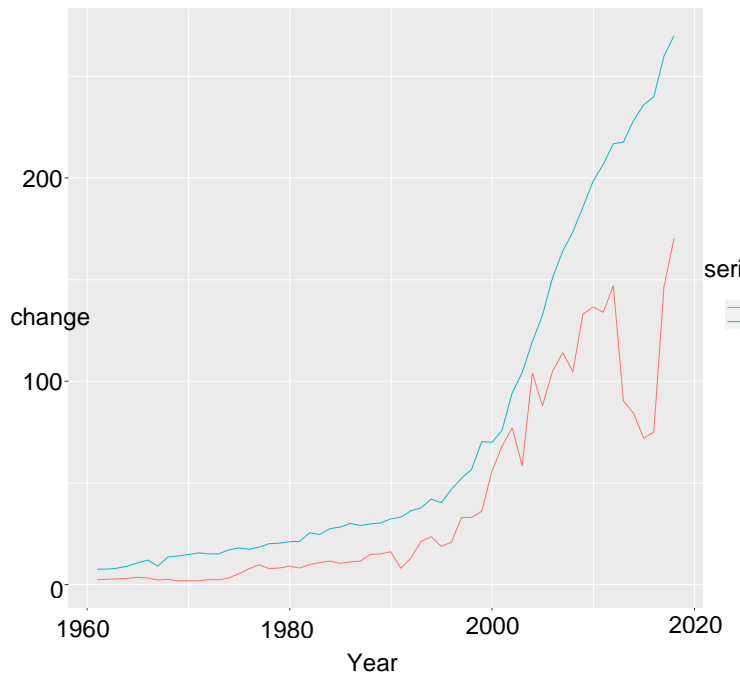

(a) Export quantity vs. production quantity from 1961 to 2018

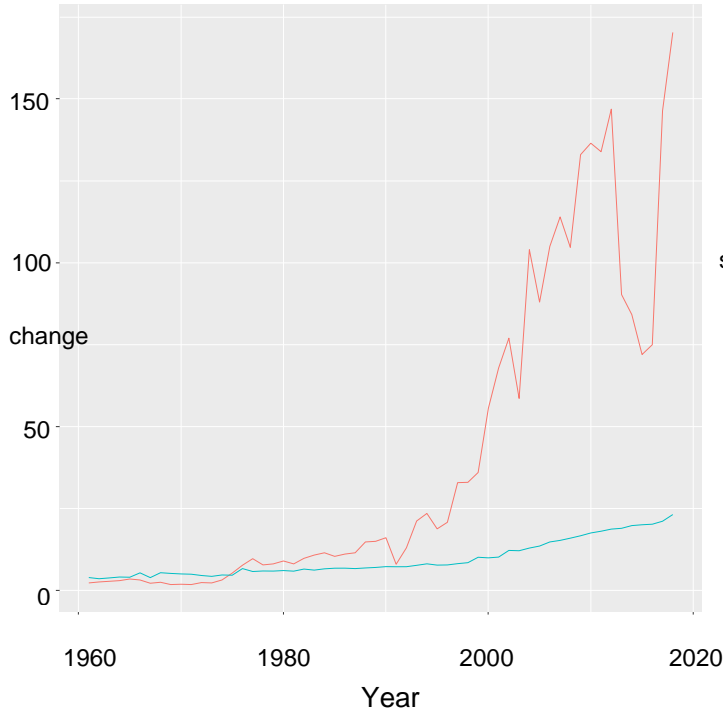

(c) Export quantity vs. productivity from 1961 to 2018

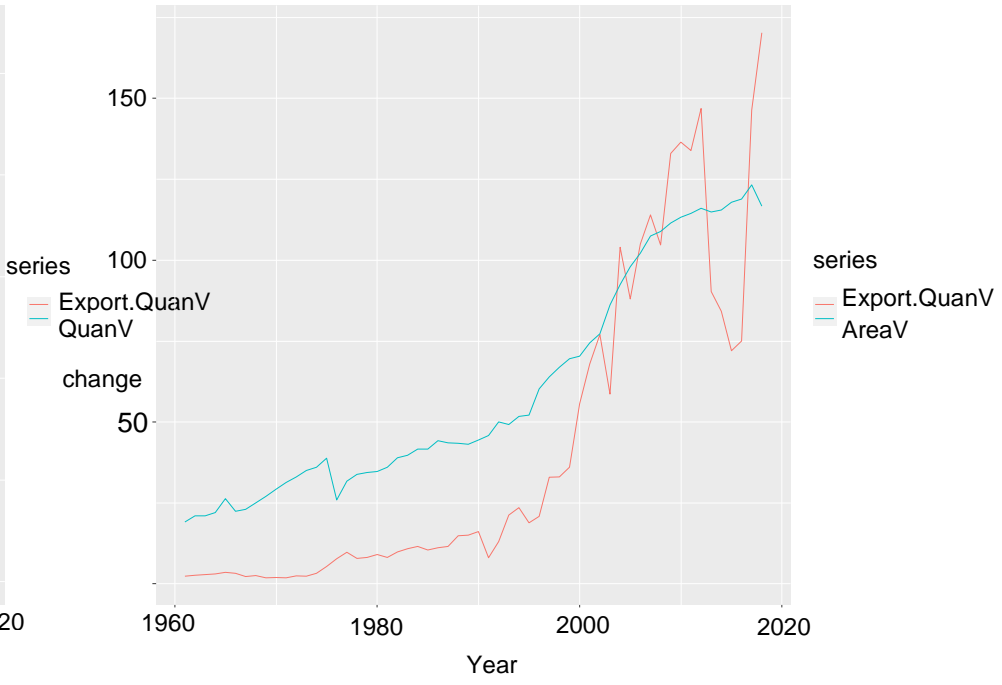

(b) Export quantity vs. production area from 1961 to 2018

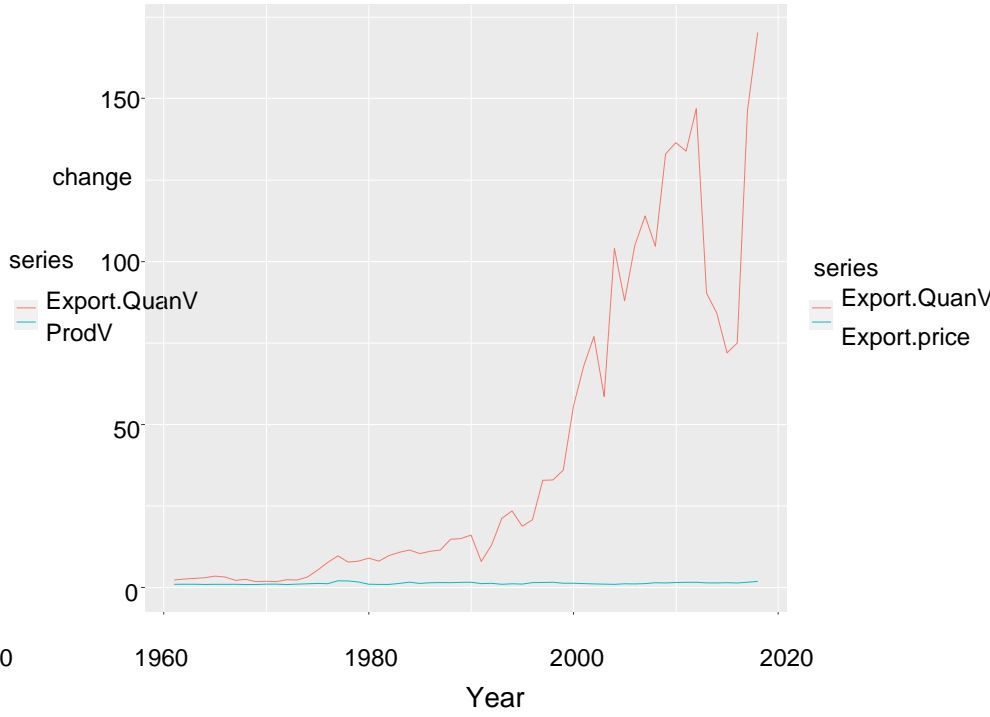

(d) Export quantity vs. export price from 1961 to 2018

Figure 2. Vietnam export quantity and other criteria from 1961 to 2018

Table 5. Descriptive statistics for the characteristics of Vietnamese tea $(n=58)$

\begin{tabular}{cccc}
\hline Variable & Unit & Mean & Std.Dev. \\
\hline Tea export quantity & $10^{3}$ tons & 40.91 & 48.36 \\
Total production area & $10^{3}$ ha & 59.91 & 34.14 \\
Total production quantity & $10^{3}$ tons & 74.50 & 80.52 \\
Tea productivity & tons ha ${ }^{-1}$ & 9.45 & 5.47 \\
Tea export price & USD kg & 1.23 & 0.27 \\
World production & $10^{3}$ tons & 2820.19 & 1481.47 \\
\hline
\end{tabular}


industry in Vietnam since 2000 via each 5-year planning stage.

All the general information of the regression promised a good model. Specifically, except for the total tea production, which had a negative and insignificant impact, the production area, export price, and tea productivity had positive significant effects on the tea export quantity of Vietnam. On average, when the cultivated tea area increased by $1,000 \mathrm{ha}$, the tea export quantity grew by 1,307 tons (Table 6). This signifies the suitability of land accumulation legislated by the government to increase the quantity of tea produced in the coming years. Similarly, when the tea productivity increased by 1 ton per ha, the tea export quantity grew by 12.096 tons, on average, when the other variables were held constant. This indicates the importance of enhancing tea productivity to the produced quantity as well as the total export quantity in which the opportunity of acquiring a larger market share of Vietnamese tea might become possible. The total produced quantity had a negative but insignificant impact on the tea export quantity; however, this points out that the majority of tea produced in Vietnam had been used domestically rather than exported. This also latently indicated that the global demand for Vietnamese tea had fallen leading to unexported tea being consumed nationally. In addition, the latent explanation for this issue might come from the rumor of "dirty tea" from Vietnam that directly led to the difficulty in exporting Vietnamese tea in the period 2013-2016.

Regarding the external factors, the tea export price and total global tea production had inverse impacts on the Vietnamese tea export quantity.
The export price was significantly positive, while the world quantity was significantly negative. Our results represent the true story of every single commercial agricultural product entering the global market. When the price went up and the global demand did not change or increased, we tended to export more. On the other hand, other countries that export tea are Vietnam's competitors in the global market and as a result, when the tea quantity of other tea exporters increased by 1,000 tons, our tea export quantity dropped by 34 tons (Table 6). To be competitive at the global scale, we need appropriate solutions to acquire a larger market share for stably developing the tea exports of Vietnam.

\section{Forecasting Vietnam's tea export quantity to 2030}

In Table 7, we observe the prediction results of Vietnam's tea export quantity up to 2030. The predictions inform us that in 2019 , the expected total tea export quantity should have reached 180.986 thousand tons, meanwhile, the total export value in 2030 might increase $231 \%$ as compared to that in 2019. However, the predicted increment pace using a conventional backtransformation was lower than using the biasadjustment method from a Box-Cox transformation. The bias-adjustment forecasted that the growth rate of the tea export quantity could reach $291 \%$ in a period of 12 years. The prediction is robust evidence for Vietnamese tea producers and policymakers to construct appropriate strategies for improving tea exports as well as acquiring of a larger market share for Vietnam in the global tea market.

Furthermore, we attempted to predict the

Table 6. Summary of the time-series linear model

\begin{tabular}{cccc}
\hline Variable & Coefficient & Std.Error & t-value \\
\hline Intercept & $-54.397^{* * *}$ & 16.118 & $(-3.375)$ \\
Total quantity & -0.206 & 0.171 & $(-0.911)$ \\
Production area & $1.307^{* * *}$ & 0.012 & $(4.773)$ \\
Export price & $11.715^{*}$ & 0.017 & $(1.816)$ \\
Productivity & $12.096^{* *}$ & 0.299 & $(2.761)$ \\
World quantity & $-0.034^{* * *}$ & $(-4.525)$
\end{tabular}

Notes: $z$-statistics are in the parentheses; *, ** and ${ }^{* * *}$ indicate significance at the 10\%, 5\%, and $1 \%$ levels, respectively. 
Table 7. Forecasting using Box-Cox transformation

\begin{tabular}{lcccc}
\hline Year & Back-transformation & Bias-adjustment & Low 95 & High 95 \\
\hline 2019 & 180.986 & 187.081 & 108.826 & 300.993 \\
2020 & 195.366 & 207.141 & 98.925 & 385.824 \\
2021 & 210.887 & 229.209 & 93.161 & 477.385 \\
2022 & 227.643 & 253.478 & 89.479 & 579.143 \\
2023 & 245.730 & 280.158 & 87.071 & 693.489 \\
2024 & 265.253 & 309.478 & 85.533 & 822.603 \\
2025 & 286.328 & 341.691 & 84.632 & 968.704 \\
2026 & 309.077 & 377.071 & 84.229 & 1134.162 \\
2027 & 333.634 & 415.917 & 84.227 & 1321.562 \\
2028 & 360.142 & 458.559 & 84.565 & 1533.757 \\
2029 & 388.756 & 505.353 & 85.196 & 1773.913 \\
2030 & 419.643 & 556.691 & 86.089 & 2045.548 \\
\hline
\end{tabular}

export quantity of Vietnam in the next 10 years by using Box-Cox transformations called simple back-transformed forecasts (median) and biasadjustments (mean). When we used the mean, rather than the median, our analysis estimated the point forecasts based on a bias-adjustment. Figure 3 illustrates the forecasted changes of tea exports up to 2030 using the two methods. It can easily be seen that the tea export quantity potentially grows at a significantly high rate. The bias-adjustment method gave us a higher increment pace of tea export quantity compared to the conventional back-transformed forecast. Therefore, in order to sustainably develop Vietnam's tea industry, the government needs to take supportive actions such as investing in indepth tea processing to improve Vietnam's tea export quality, focusing on post-harvest activities, investing in organic or high-value tea rather than conventional tea, continuing to accumulate land to support the growth of cultivated tea areas, and maintaining high productivity by using hybrid seeds.

The two major competitors of Vietnamese tea exports, India and Sri Lanka, have also been predicted to have an upward trend of total tea production. Ghosh (2017) studied the potential trend of India's tea exports using 79 months of data and produced results similar to ours. Similarly, Kumarasinghe et al. (2018) argued that Sri Lanka also possessed a bright future of either producing or exporting tea in larger quantities. In addition, Chang (2015) predicted an increment of global tea export quantity up to 2030. In this context, the Vietnamese tea sector should rely on these published data to carefully plan for developing tea production effectively and sustainably.

\section{Conclusions}

The study provided an overview of the Vietnamese tea export situation across 58 years from 1961 to 2018. Generally, the tea exports of Vietnam have had an upward trend, however, Vietnam witnessed a significant fall of the tea export quantity during 2013-2016, although the tea export price slightly increased. We employed a time-series linear model to estimate the relationship between the tea export quantity and its determinants. Except for the total domestic quantity, the production area, export price, and productivity had positively significant impacts on the tea export quantity, while the world tea production had a negatively significant effect.

Our results suggested that in areas where tea was planted, tea productivity increased the tea export quantity, meanwhile, due to the rise of other countries exporting tea of a higher quality than Vietnamese tea, the tea export quantity led 


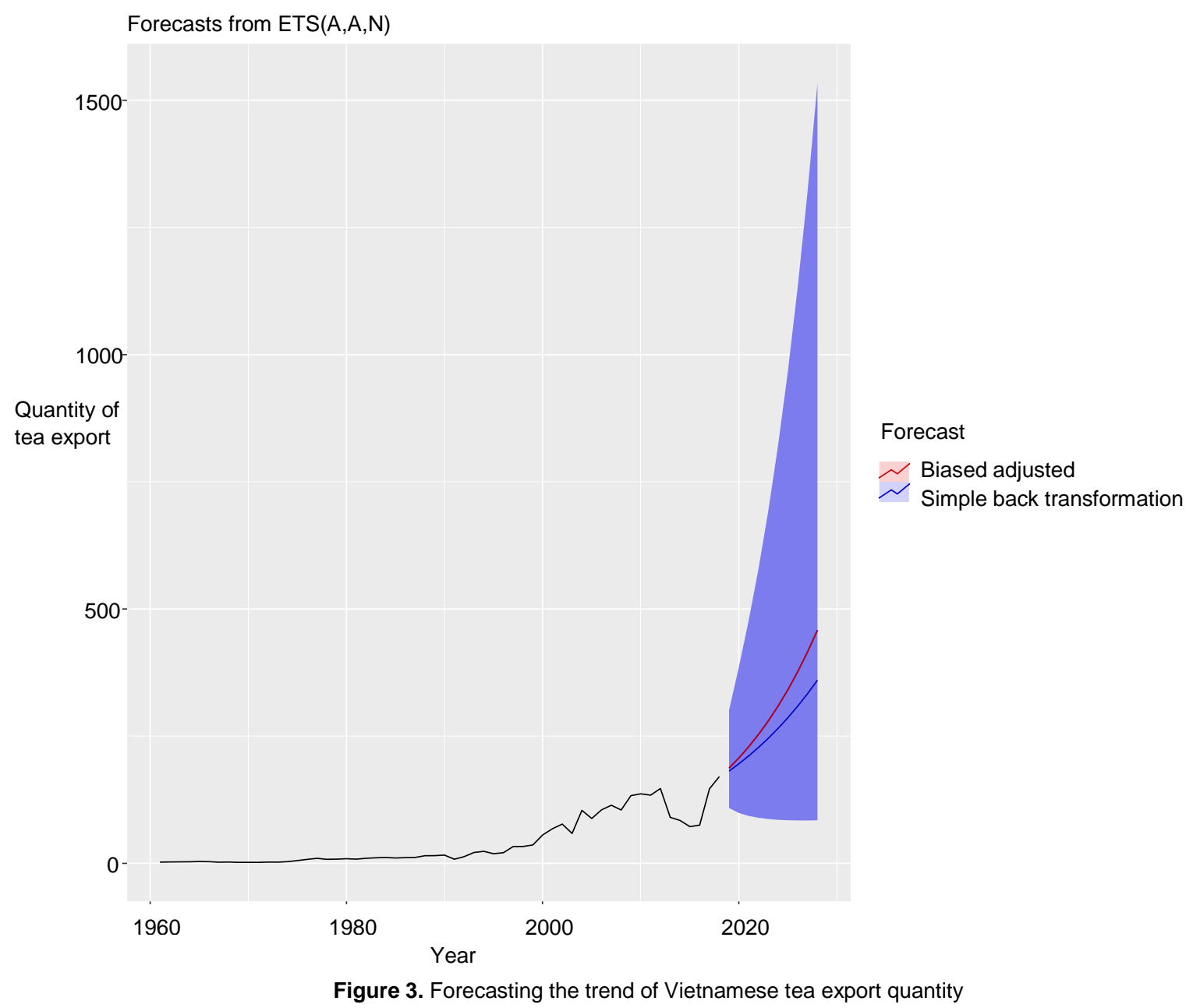

to the downfall of tea exports. The tea price had the least fluctuation, which could potentially secure a good fortune if Vietnam could export a larger tea quantity. Therefore, in order to sustainably develop Vietnam's tea industry, the government needs to take supportive actions such as investing in in-depth tea processing to improve Vietnam's tea export quality, focusing on post-harvest activities, investing in organic or high-value tea rather than conventional tea, continuing to accumulate land to support the growth of cultivated tea areas, and maintaining high productivity by using hybrid seeds.

Box-Cox transformations called simple back-transformed forecasts and bias-adjustments were used to forecast the growth rate of Vietnamese tea export quantities until 2030. Our result forecasted an upward trend for Vietnamese tea export quantities up to 2030, which signifies a bright future for the export of Vietnamese tea. However, the domestic tea market should also be developed in order to increase the consumption of domestic tea. Our analysis opened the door for further research on Vietnamese tea exports in order to account for the impacts of the TransPacific Partnership (TPP) and Regional Comprehensive Economic Partnership (RCEP).

\section{References}

Amirkhalkhali S. \& Dar A. A. (1995). A varyingcoefficients model of export expansion, factor accumulation and economic growth: Evidence from cross-country, time series data. Economic Modelling. 12(4): 435-441.

Chang K. (2015). World tea production and trade Current and future development. Food and Agriculture Organization Of The United Nations, Rome.

Cuong Q. M. (2006). Research the type the link between production and processing, consumption of tea on Thanh Ba district, Phu Tho province. Master's thesis, Hanoi University of Agriculture, Vietnam (in Vietnamese). 
FAO (2019). FAOSTAT. Retrieved on May 5, 2019 at http://www.fao.org/faostat/en/\#data.

Ghosh S. (2017). Forecasting Exports of Tea from India: Application of Arima Model. Journal of Commerce and Trade. 12(2): 116-129.

GSO (2019). Statistical summary book of Vietnam 2018. General Statistics Office (in Vietnamese).

Kingu J. (2016): Determinants of Export Performance of Tea in Tanzania: Parametric and Non-Parametric Analysis. Amity Business Review. 11(7): 173-183.

Kumarasinghe H. P. A. S. S. \& Peiris B. L. (2018). Forecasting annual tea production in Sri Lanka. Tropical Agricultural Research. 29(2): 184-193.

Miano G. W. (2010). Determinants of tea export supply in Kenya (1970-2007). Ph.D. thesis, University of Nairobi, Kenya.

Petrakis P. E., Kostis P. C. \& Valsamis D. G. (2015). Innovation and competitiveness: Culture as a longterm strategic instrument during the European Great Recession. Journal of Business Research. 68(7): 1436-1438.
Saigenji Y. \& Zeller M. (2009). Effect of contract farming on productivity and income of small holders: The case of tea production in north-western Vietnam. International Association of Agricultural Economists Conference, Beijing, China - September 2009.

Serletis A. (1992): Export growth and Canadian economic development. Journal of Development Economics. 38(1): 133-145.

Tran T. C., Samman E. \& Rich K. (2004). The participation of the poor in agricultural value chains: A case study of tea. Asian Development Bank, Hanoi, Vietnam October 2004.

Tuan A. N. \& Nguyen T. T. (2019). Efficiency and adoption of organic tea production: Evidence from Vi Xuyen district, Ha Giang province, Vietnam. Asia-Pacific Journal of Regional Science. 3(1): 201-217.

Uk Polo V. (1994). Export composition and growth of selected low-income African countries: Evidence from time-series data. Applied Economics. 26(5): 445-449.

Vitas (2012). The 2011 Vietnam Handbook of Tea. Vietnam Tea Association, Hanoi, Vietnam (in Vietnamese). 